
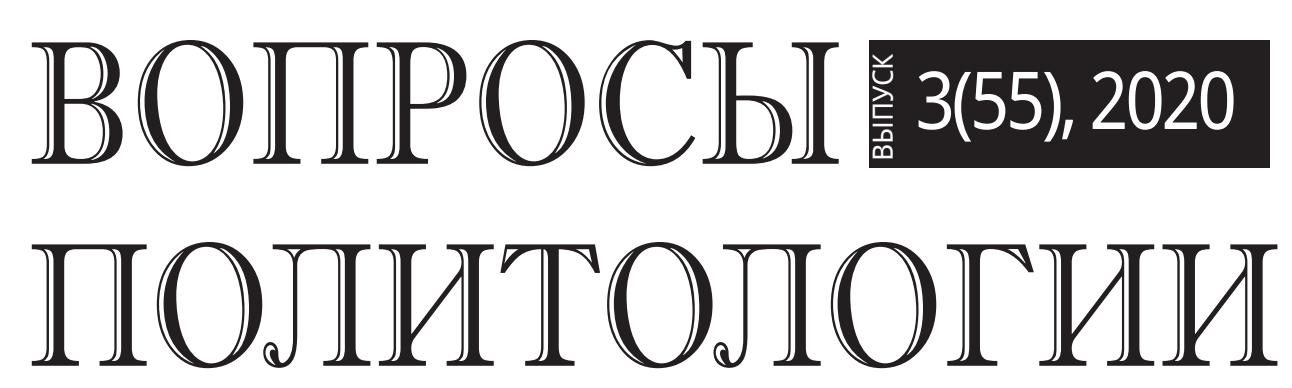

Научный журнал

Журнал «Вопросы политологии» включен

в Перечень рецензируемых научных изданий

BAK Министерства образования и науки РФ по политическим наукам, в которых должны быть опубликованы основные научные результаты на соискание ученой степени кандидата наук,

на соискание ученой степени доктора наук

Журнал включен в Перечень научных изданий рекомендованных ВАК Республики Узбекистан для публикации основных научных результатов диссертаций по политическим и философским наукам 
Председатель Редакционного Совета - ПЛАТОНОВ В.М.,

К.ю.н., заведующий кафедрой политического анализа и управления РУДН, Председатель Московской городской Думы (1994-2014 гг.)

\section{Редакционный Совет}

\section{АСТВАЦАТУРОВА}

Майя Арташесовна

БОЖАНОВ

Владимир Александрович

ВЕДРИН

Оливье

ДОНАЙ

Лукаш

ЖИЛЬЦОВ

Сергей Сергеевич

ИРХИН

Юрий Васильевич

\section{КАРАДЖЕ}

Татьяна Васильевна

КЕТЦЯН

Григор Ваникович

\section{КОВАЛЕНКО}

Валерий Иванович

КРИВОКАПИЧ

Борис

МЕДВЕДЕВ

Николай Павлович

МИХАЙЛОВ

Вячеслав Александрович

\section{НАСИМОВА}

Гульнара Орленбаевна

\section{НИСНЕВИЧ}

Юлий Анатольевич

Шукритдин Ильясович

ПЛЯЙС

Яков Андреевич

ПРЯХИН

Владимир Федорович

ПУСЬКО

Виталий Станиславович

\section{ХОПЁРСКАЯ}

Лариса Львовна

\section{ПАХРУТДИНОВ}

д.п.н., профессор, директор Центра этнополитических исследований, профессор кафедры креативноинновационного управления и права Пятигорского государственного университета, координатор Сети этнологического мониторинга и раннего предупреждения конфликтов в СКФО (Россия, г. Пятигорск)

д.и.н., профессор, зав. кафедрой мировой и отечественной культуры Белорусского Национального технического университета (Белоруссия, г. Минск)

профессор, главный редактор русской версии французского журнала «Национальная оборона» (Revue Défense Nationale), спикер Европейской комиссии, редактор франко-германского журнала по вопросам внешней политики «European Union Foreign Affairs Journal» и ректор «Континентального университета в Киеве» (Франция, г. Париж)

Д.п.н., профессор факультета политологии и журналистики Департамента международных отношений Университета им. Адама Мицкевича в Познани (Польша, г. Познань)

д.п.н., заведующий кафедрой политологии и политической философии Дипломатической академии МИД РФ (Россия, г. Москва)

д.ф.н., профессор кафедры политологии и политического управления РАНХ и ГС при Президенте РФ (Россия, г. Москва)

д.ф.н., заведующая кафедрой политологии и социологии МПГУ (Россия, г. Москва)

к.П.Н., заместитель Главного редактора журнала, Председатель Попечительского Совета научного журнала «Вопросы политологии» (Россия, г. Москва) д.ф.н., зав. кафедрой российской политики МГУ им. М.В. Ломоносова (Россия, г. Москва) д.ю.н., профессор факультета бизнеса и права Унион Никола Тесла университета (Сербия, Белград)

д.п.н., профессор кафедры анализа и управления Российского университета дружбы народов, главный редактор журнала (Россия, г. Москва) д.и.н., зав. кафедрой национальных и федеративных отношений РАНХ и ГС при Президенте РФ (Россия, г. Москва)

д.п.н., профессор, зав. кафедрой политологии факультета философии и политологии Казахского Национального университета им. Аль-Фараби (Казахстан, г. Алматы) д.п.н., профессор Национального исследовательского университета «Высшая школа экономики» (Россия, г. Москва)

д.п.н., профессор, заведующий кафедрой основы духовности Института переподготовки и повышения квалификации руководителей и специалистов системы народного образования имени А. Авлони (Узбекистан, г. Ташкент)

д.и.н., д.п.н., профессор Финансового университета при Правительстве РФ (Россия, г. Москва)

д.п.н., профессор кафедры зарубежного регионоведения и внешней политики РГГУ (Россия, г. Москва)

д.ф.н., профессор кафедры гуманитарных дисциплин ВА РВСН им. Петра Великого (Россия, г. Москва)

д.п.н., профессор кафедры международных отношений Киргизско-Российского славянского университета, (Киргизия, г. Бишкек)

\section{Редакщионная коллегия}

Главный редактор - МЕДВЕДЕВ Н.П., д.П.н., профессор

Абрамова О.Д. (д.п.н.)

Насимова Г.О. (д.п.н.)

Кетцян Г.В. (к.п.н. - зам. гл. редактора)
ISSN 2225-8922

ЖУРНАЛ ВКЛЮЧЕН В ПЕРЕЧЕНЬ ВАК РФ

\section{УЧРЕЖДЕН}

ООО «Издательство «Наука сегодня»

Журнал зарегистрирован

Федеральной службой по надзору в сфере массовых коммуникаций, связи и охраны культурного наследия

\section{Рег. № ПИ № ФС77-46176} от 12 августа 2011 г.

Журнал издается ежемесячно

Журнал включен в базу РИНЦ (Российский индекс научного цитирования)

Включен в каталог Ulrich's Periodicals Directory

Пятилетний импакт-фактор: 1,489.

Адрес редакции: 115598 , г. Москва, ул. Загорьевская, д. 10, корп. 4, цокольный этаж, помещение I, комната 7-1, офис 4 Тел.: (910) 463-53-42

Интернет-ресурс: www.voprospolitolog.ru E-mail: voprospolitolog@yandex.ru

Мнение авторов может не совпадать с мнением редакции. При перепечатке ссылка на журнал обязательна.

Научные статьи, публикуемые в журнале подлежат обязательному рецензированию.

Ответственный редактор Шкурина С.С.

Перевод

Чернышова Е.В.

Компьютерная верстка Анциферова А.С.

Подписано в печать 25.03.2020

Формат 60×84/8. Объем 24,3.

Печать офсетная.

Тираж - 1000 экз.

(1-й завод - 500 экз.) Заказ № 50376.

Отпечатано в типографии PrintUP 117105 , г. Москва, Нагорный проезд, 12, корп. 1 Тел.: +7 (495) 925-00-06 
ISSN 2225-8922 (print)

12 выпусков в год и

4 выпуска в год переводной (англ.) версии

Языки: русский, английский

http://voprospolitolog

Входит в перечень рецензируемых научных изданий ВАК РФ

Включен в каталог периодических изданий Ульрих

(Ulrich's Periodicals Directory: http://www.ulrichsweb.com)

Материалы журнала размещаются на платформе РИНЦ

Российской научной электронной библиотеки, Electronic Journals Library Cyberleninka

Подписной индекс издания в каталоге агентства Роспечать 70035

\section{Цели и тематика}

Журнал ВОПРОСЫ ПОЛИТОЛОГИИ - периодическое международное рецензируемое научное издание в области политических исследований. Журнал является международным как по составу редакционного совета и редколлегии, так и по авторам и тематике публикаций.

Научный журнал издается с 2011 года в издательстве «Наука сегодня». С 2016 года издается переводная (англ.) версия журнала. С момента своего создания, журнал ориентировался на высокие научные и этические стандарта и сегодня является одним из ведущих политологических журналов России.

Цель журнала - способствовать научному обмену и сотрудничеству между российскими и зарубежными политологами.

Журнал предназначен для публикации результатов фундаментальных и прикладных научных исследований. Тематическая направленность журнала отражается в следующих постоянных рубриках: «История и философия политики», «Политические институты, процессы и технологии», «Политическая регионалистика и этнополитика», «Политическая культура и идеологии», «Политические проблемы международных отношений и глобализации».

Формат публикаций: научные статьи, обзорные научные материалы, материалы круглых столов, научные рецензии, научные сообщения, посвященные исследовательским проблемам в сфере политики и политологии.

В своей деятельности редакционный совет и редколлегия журнала руководствуется принципами, определяемыми ВАК России для научных журналов, в том числе: наличие института рецензирования для экспертной оценки качества научных статей; информационная открытость издания; наличие и соблюдение правил и этических стандартов представления рукописей авторами

Целевой аудиторией журнала являются российские и зарубежные специалисты-политологи, а также аспиранты и магистры, обучающиеся по направлениям политология, государственное и муниципальное управление и международные отношения.

Журнал строго придерживается международных стандартов публикационной этики, обозначенных в документе СОРЕ (Committee on Publication Ethics) http://publicationethics.org

Полные сведения о журнале и его редакционной политике, требования о подготовке и публикации статей, архив (выпуски c 2011 года) и дополнительная информация размещена на сайте: http://voprospolitolog.ru

Электронный адрес: voprospolitolog@yandex.ru

ISSN 2225-8922 (print)

12 issues a year plus 4 issues a year of the translated (eng.) version Languages: Russian and English http://voprospolitolog

Included in the list of peer-reviewed scientific publications of the Higher Attestation Commission of the Russian Federation Included in the Ulrich's Periodicals Directory Materials of the journal are placed on the RSCI platform of the Russian scientific electronic library - Electronic Journals Library Cyberleninka Subscription index of the journal in the Rospechat Agency catalogue is: 70035

\section{Objectives and themes}

Academic journal "Political Science Issues" is an international peer-reviewed scientific periodical in the field of political studies. The journal has an international character because of the composition of its Editorial Board, its editors, its contributing authors and topics of its publications.

The scientific journal is published since 2011 at the "Publishing House "Science Today". Translated (eng.) version of the journal is published since 2016. Since its inception, the journal was guided by high scientific and ethical standards and today it is one of the leading political science journals in Russia.

The purpose of the journal is to promote scientific exchange and cooperation between Russian and foreign political scientists.

The journal is intended for the publication of the results of fundamental and applied scientific research. Thematic focus of the journal is reflected in the following permanent headings: "History and philosophy of politics," "Political institutions, processes and technologies," "Political regionalism and ethno-politics," "Political culture and ideologies," "Political problems of international relations and globalization."

Format of publications: scientific articles, reviews, scientific materials, materials of round tables, scientific reviews, scientific reports devoted to research problems in the field of politics and political science.

The Editorial Board and the editors of the journal in their activities are guided by the principles defined by VAK of Russia for scientific journals, including: presence of the institute of peer review for the expert quality assessment of scientific articles; information openness of the publications; availability and compliance with the rules and ethical standards for the submission of manuscripts by the authors.

The target audience of the journal is Russian and foreign specialists-political scientists, as well as graduate students and masters in the fields of political science, state and municipal management and international relations.

The journal strictly adheres to the international publishing standards and publication ethics identified in the COPE (Committee on Publication Ethics) document. http://publicationethics.org.

Full details of the journal and its editorial policy, requirements to the preparation and publication of articles, archive (issues since 2011) and additional information are available on the website: http://voprospolitolog.ru

E-mail address: voprospolitolog@yandex.ru 


\section{ТЕОРИЯ, ФИЛОСОФИЯ И ИСТОРИЯ ПОЛИТИКИ}

Гаджиев К.C. Проект «Один пояс, один путь»

в геополитическом измерении ....

Николенко А.А., Тушков А.А. К вопросу о методологических

основах исследования подходов к проблемам локальных цивилизаций.

Azапов П.В. Религия в творчестве Эриха Фромма:

социально-психологические аспекты проблемы

\section{ПОЛИТИЧЕСКИЕ ИНСТИТУТЫ, ПРОЦЕССЫ И ТЕХНОЛОГИИ}

Румянцев О.Г. О некоторых политологических аспектах конституционной реформы 2020 года в Российской Федерации

Пустовойт Ю.А., Антонов К.А. «А и Б сидели на трубе»:

конструирование протестной идентичности в ходе «тарифной войны»

в Новосибирске (2016-2017 гг.)

Артемьев A.A., Пыхтин С.H. Новые медиа как инструмент влияния на политические процессы в современном российском обществе

Бакшеева А.Р., Гусарская Т.А., Беляева В.П. Особенности реализации государственной антикоррупционной политики в современной России: механизм государственного контроля в контрактной системе государственных закупок

Булах Е.В., Князева А.P., Цой В.Г. Трайбализм

на Дальнем Востоке России: остаточные проявления

регионального колорита или новые формы.

Воронина Н.А. Политика интеграции мигрантов и беженцев в странах ЕС ...... 782

Kрюкова $\boldsymbol{E} . \boldsymbol{B}$. Роль общественно-политических организаций

в урегулировании политических конфликтов: возможности и перспективы

Галкина Г.M. Образовательная политика в программах

политических партий (на примере Коммунистической партии

Российской Федерации и Справедливой России)

Ворончихина Д.Н. Роль Ассоциации «Арктические муниципалитеты»

при осуществлении государственной политики в арктической зоне

Российской Федерации......

МЕЖДУНАРОДНЫЕ ОТНОШЕНИЯ И МИРОВАЯ ПОЛИТИКА

Михайленко А.Н. Как раскрывать

внешнеполитический потенциал России?

Mypaвbx A.И., Никитенко E.Г. Запад против обнуления

президентских сроков в России

Сергеева С.Л., Гапонов П.В. Практика реализации проектов

на основе муниципально-частного партнерства в Российской Федерации

и странах Европейского Союза: сравнительный анализ 
Tетерюк A.C. Анализ распределения результатов выборов в парламент Финляндии в ходе четырех электоральных циклов

Хлопов О.А. Энергетическая безопасность

Европейского союза: между Россией и США

Костоев 3.И., Арапханова Л.Я. Северный Кавказ

в контексте международной политики

Kaратуева $\boldsymbol{E} . \boldsymbol{H}$. Проблемы и предотвращение

продовольственного терроризма

Жамбаева У.Б. Буддизм Тибета в политическом контексте династии Юань.

Султанова A.P. Концептуальные подходы к формированию

национальной модели развития гражданского общества в Узбекистане

Афонин А.Д. Выход стран Балтии

из энергокольца БРЭЛЛ: причины и следствия

Петрова К.С. Профилактика исламского экстремизма

и терроризма в Республике Татарстан

Балданова P.A. Совместный университет «МГУ-ППИ в Шэньчжэне»

как часть миграционной политики КНР

Адум Кагер, Шуленина Н.В. Китай и Африканский союз:

проблемы и перспективы

Джавад O.B. Языковые аспекты обеспечения

социетальной безопасности в странах Западной Европы

Юлдашева М.К. Критерий информационной безопасности

в процессах межкультурной интеграции

Усмонов С. Общечеловеческие принципы

и особенность национальной идеи (идеологии) в Узбекистане

Еремина Я.В. Информационные технологии

как инструмент «мягкой силы»

Шолкова М.А. Безопасность и ее обеспечение на различных геополитических уровнях

Гао Дай Антикоррупционное противодействие в Китае:

история и современность

Чэнь Ханьчжи Развитие системы госслужбы КНР

как механизм формирования политических элит

Агоннуде Бидолей Вианней Фредди ЮАР и ООН:

аспекты взаимодействия.

Олувакайоде Олумиде Эммануэль, Мугаби Брайан, Джу Орлинду

Ключевые проблемы Африки/The Plagues of Africa

Чэн Го, Буторов А.С., Инь Цюнь Политический анализ

китайско-американской торговой войны и ее последствий/

The Political Analysis of the Sino-U.S. Trade War and Implications 
Ванграуа Садиа Рита Сониа, Егези Блессинг Чиманпа Отношения между Буркина-Фасо и Тайванем в период с 2000 года по 2018 год 1013

Лученков И.Р. Процессы политической интеграции в странах

Большого Ближнего Востока в рамках панарабистской концепции периода 1945-1990 гг..

\section{РАЗМЫШЛЕНИЯ НАД ПРОЧИТАННЫМ}

Слизовский Д.Е., Медведев Н.П. Послесловие к статье Румянцева О.Г. «О некоторых политологических аспектах конституционной реформы 2020 года в Российской Федерации» 1029

НАШИ АВТОРЫ 1038

ТРЕБОВАНИЯ К ОФОРМЛЕНИЮ РУКОПИСЕЙ 1047 


\section{ПРОЦЕССЫ ПОЛИТИЧЕСКОЙ ИНТЕГРАЦИИ В СТРАНАХ БОЛЬШОГО БЛИЖНЕГО ВОСТОКА В РАМКАХ ПАНАРАБИСТСКОЙ КОНЦЕПЦИИ ПЕРИОДА 1945-1990 ГГ.}

В статье рассматривается необходимость экономических, политических интеграционных процессов в арабских странах Большого Ближнего Востока, а также причины их несостоятельности в данном регионе во второй половине XX века.

Ключевые слова: интеграция, исламизм, консолидаџия, ЛАГ, панарабизм, арабский национализм, арабский сощиализм, арабское сотрудничество.

Политическая интеграция - объединение, слияние межгосударственных структур, политических институтов с целью достижения политической, экономической и/или культурной общности, стабильности в развитии государств и обществ. Широкое распространение этого процесса наиболее характерно для второй половины XX века: окончание Второй мировой войны подтолкнуло государства к идее консолидации для скорейшей реабилитации и достижения общих результатов, а также предотвращения возможного государства-гегемона на международной арене [2; 15]. Вопреки популярному мнению, что объединения коснулись лишь европейских стран, интеграционные процессы в различных проявлениях сыграли важнейшую роль в развитии Ближнего Востока.

Ключевыми путями интеграции в регионе арабского Востока являлись национализм и исламизм. По мнению проевропейских арабоязычных интеллектуалов, идеи объединения только на основе ислама изжили себя и не соответствуют актуальным на тот момент общемировым тенденциям. В связи с этим единственной альтернативой для воссоединения Арабских общностей была идея национализма, воплощенная в концепции панарабизма и секуляризации политической жизни.

Подчеркивая объединение на основе языка, общей истории и происхождения и противопоставляя данную модель, отстаиваемому Османами, 
традиционному исламскому универсализму, Аль-Кавакиби смог изменить границы «арабской» общности, обосновав необходимость борьбы против турок по националистическим, а не по религиозным мотивам. По его мнению, арабы являются основой ислама, носителем его послания, поэтому всегда являлись особой «нацией» - арабской уммой. Для обоснования данной концепции он использовал теорию Ибн Халдуна о взлете и падении цивилизаций, чтобы доказать, что арабская национальная идея переосмысляется, а не создается [10]. К середине XX века арабская интеллигенция накопила достаточно эмпирического опыта, необходимого для продвижения панарабизма в народные массы.

Аль-Хусари также обозначал язык и историю как факторы, определяющие арабскую идентичность, и исходящего из нее национализма. По его словам, «люди, которые говорили на одном языке, имеют одно сердце и общую душу. Как таковые, они составляют одну нацию, и поэтому они должны иметь единое государство» Арабские государства являются искусственными политическими созданиями, и разделение арабской нации на эти отдельные государства стало причиной поражения арабов в палестинской войне 1947-1949 гг. [8]. Идеи панарабизма находились под сильным влиянием немецкого романтического национализма XIX века. Политическим выражением этих идей было то, что у арабов должно быть одно демократическое и светское государство, их всеобщее объединение на пространстве всего Ватан аль-Араб: от Арабского залива до Атлантического океана.

Также классики панарабизма настаивали: разъединение арабских стран мешает политическому, экономическому, военному и культурному развитию; только лишь стерев выдуманные границы внутри Арабского мира, возможен прогресс.

Военная и политическая отсталость арабских государств стала наиболее очевидна во время прямого противостояния. Не согласные с резолюцией генеральной ассамблеи ООН «О разделе Палестины» Ирак, Йемен, Египет, Саудовская Аравия, Ливан, Трансиордания были вынуждены ввести регулярные войска на территорию Палестины для защиты своих интересов. Но несмотря на теоретическое согласие этих стран в отстаивании единых позиций в войне с новообразованным Израилем, фактически они были разобщены [12].

Поражение в войне с Израилем показало невозможность дальнейшего институционального политического и экономического развития арабских государств по модели конституционных либеральных монархий. В данных условиях начался процесс проникновения в идеологию панарабизма социалистических воззрений. Одновременно с этим региональный национализм интеллигенций сдвигался в сторону национализма Великой Арабской Родины. 1930-40-ые гг. полюсом данных преобразований стала республиканская Сирия, находившаяся под французским мандатом [5]. Для интеграции 
арабскому обществу поствоенного периода требовалось всестороннее обновление, но для панарабистов тех лет это должно было быть не исламское возрождение - ан-Нахда аль-Исламийя, а социалистическое - аль-Баас альИштиракийя.

Влиятельным политическим движением, выступавшим против французского присутствия, была, основанная в 1932 г. Антуном Саада, происходившим из греко-православной среды, Сирийская Социал-националистическая партия, придерживавшаяся концепции сирийской нации, выступавшей оппозицией панарабизму и панисламизму. Мишель Афляк придерживался противоположной концепции, выступая за исламскую идентичность сирийского общества как составной части Арабского мира. Он критиковал марксистское прочтение диалектического материализма, утверждая, что ислам является революционным движением, и первым «революционером» был пророк Мухаммад, приведший арабскую нацию к возрождению (аль-Баас) [13].

Согласно данной идеологии, арабская нация являлась устойчивой во времени и пространстве константой, направляемой панарабистами для борьбы с европейским и «сионистским» империализмом.

В 1939 г. Мишель Афляк вместе с аль-Битаром выпускают антифранцузский журнал политической направленности «Харакят аль-Ихъя аль-'Араби», который дал имя для созданной ими партии. В 1941 г. она переименовывается в «аль-Баас аль-'Арабийя», в это же время существовала одноименная националистическая партия, основанная Заки аль-Арсузи, что привело к конфликту с последним. Но 7 апреля 1947 г. оба движения объединяются в «хизб ль-Баас аль-'Араби аль-Иштираки», чье название на русский язык может переводиться одновременно как «Партия арабского социалистического возрождения», так и «Арабская социалистическая партия возрождения», что во многом объясняет двойственный характер политического курса партии, предопределивший раскол 1966 г. Подобная терминологическая дихотомия являет типичную для арабского национализма проблему неточности понятийной составляющей данной идеологии: примером также могут послужить неоднозначность термина «араб» или «Арабский мир» [7].

Девизом партии стало: «Единство, свобода, социализм». «Единство» ставилось на первое место, исходя из националистической трактовки слова «вахида», подразумевавшее единение всего арабского мира. «Хуррийя» понималась как свобода от европейского колониализма и сионизма: лишь через единство арабского мира возможна его полная политическая независимость. «Иштиракийя» имеет общий корень с такими понятиями как «мушарака»общность, «ширака» - соучастие, «иштирак»- соединение, соучастие, - это говорит о том, что партия не ставила перед собой цель построения коммунизма и не исключала капиталистическую модель экономики. В арабском сознании «социализм» лишен марксистского подтекста, касающегося экономического базиса, переданного во владение рабочему классу. 
Толчком популяризации панарабизма стала Июльская революция в Египте, низвергнувшая 23 июля 1952 г. короля Фарука силами движения «Свободные офицеры». Армейские активисты в большинстве своем не имели четко выраженной идеологической составляющей, а руководствовались лишь принципом, что монархия, обеспечивающая европейские интересы в своей собственной стране, препятствует ее развитию. Сам приход к власти военных обозначил вектор формирования новой египетской внутренней и внешней политики - революционность и ориентация на уход от традиционализма в формировании общественного бытия. В дальнейшем для построения собственной вертикали власти республиканское правительство взяло за основу советскую модель бюрократического, громоздкого и часто не эффективного, аппарата. Борьба с религией и полный отказ от исламских корней не нашла бы отклик в широких народных массах, данное обстоятельство предопределило выбор в пользу панарабистской секулярной идеологии. Стоящий особняком египетский национализм усилиями Гамаля Абдель Насера заменялся арабским, однако данная модель скорее относилась к тезису «Египет - центр Арабского мира», предполагавшему единственный путь политической интеграции: поглощение Египтом [1].

Заданная Египтом модель панарабизма противоречила фундаментальным основам данной идеологии ввиду того, что она не была демократической. Насер, став президентом страны, выстраивал вокруг себя культ личности, чью модель поведения переняли другие лидеры, проводившие активную панарабистскую политику.

Приватизация Суэцкого канала и земельная реформа сделали его авторитет незыблемым. По своей сути такая политика даже не была идейным продолжением египетского национализма, это была политика одного человека. Насер, пользуясь авторитетом, начал лоббировать египетскую экспансию в политическую жизнь арабских стран. Пользуясь тем, что в Сирии к власти пришли баасисты, в 1958 г. Насер отправляет делегацию в Дамаск, которая предложила идею объединения Египта и Сирии. По своей сути это была вторая попытка построения единого арабского государства.

В годы монархии Египет также пытался создать объединенную арабскую конфедерацию, но это у него не получилось ввиду конфликтов интересов по поводу будущего политического устройства страны между республиканскими Ливаном и Сирией и либерально-монархическими Египтом, Трансиорданией, Ираком и абсолютистско-теократическими Саудовской Аравией и Мутаваккилийским королевством Йеменом [9].

Из этой попытки в итоге была сформирована Лига арабских государств, которая в свою очередь являла собой продукт арабского сотрудничества, а не арабской интеграции. Ключевой особенностью, препятствующей консолидации государств-членов внутри ЛАГ был «страновый» характер политического взаимодействия внутри организации, определяющей незави- 
симые арабские сообщества «суверенными народами», формирующими единую арабскую нацию [4].

Гамаль Абдель Насер же предлагал полностью республиканский арабский интеграционный проект. 21 февраля 1958 г. в Египте и Сирии произошел народный референдум об объединении двух стран в единое государство. Так была создана Объединенная Арабская Республика, а Насер стал ее президентом. Но данное образование было лишь де-факто федерацией: все руководящие посты в нем занимали египтяне, фактически Сирия была ликвидирована, как государство, в документах она числилась, как «северные территории».

Насер начал проводить аналогичные египетским реформы, в том числе в 1960-1961-е гг. запретил деятельность политических партий в Сирии. Однако недовольные сирийские военные захватили власть на территории Сирийской Республики и в 1961 г. в одностороннем порядке вышли из состава федерации.

В этот же период (1958 г.) была предпринята попытка арабских монархий дать ответ республиканскому панарабизму. На территории Ирака и Иордании правила общая династия, династия Хашимитов, на протяжении 1930-40-ых гг. предпринимавшая попытки объединения. В ускоренном порядке короли Хусейн и Фейсал II объединяют свои государства в конфедерацию - Арабскую Федерацию Ирака и Иордании. Это объединение было очень недолговечным: пример свободных офицеров дал толчок для революционного движения по всему Арабскому миру и 14 июля 1958 г. иракская монархия пала, король Фейсал был убит, что предопределило распад данного политического альянса [9].

ОАР имело неоспоримые преимущества: ее устав предусматривал вхождение в ее состав любого арабского государства. Таким образом, 8 марта 1958 г. между ОАР и Северным Йеменом был заключен конфедеративный договор. Однако Йемен оставался практически полностью независимым государством. Но теократическая монархия не могла состоять в одном политическом объединении с секулярными государствами. В связи с этим пронасеровски настроенные офицеры при поддержке части племенных конфедераций свергли монархию в Йемене и провозгласили республику.

Вплоть до смерти Насера ОАР функционировала лишь на территории Египта. но он не оставлял попыток сплотить арабские государства. Поводом продемонстрировать национальную солидарность стала новая война коалиции во главе с Египтом против Израиля в 1967 г., закончившуюся очередным поражением и оккупацией Синайского полуострова, Голанских высот, Западного берега реки Иордан и сектора Газа.

1971 год стал новым этапом в арабском интеграционном строительстве, выраженном появлением два новых проекта панарабских объединений: Федерация Арабских княжеств Персидского залива и Федерация Арабских Ре- 
спублик, первый из которых не был суверенной арабской инициативой, а попыткой британской колониальной администрации по реорганизации своих аравийских протекторатов. Отметим, что влияние внешних сил на процесс этнической консолидации само по себе имеет негативный оттенок интервенционизма и заранее не может быть успешным. Получившие полную независимость правители Кувейта, Катара, Бахрейна, не хотели делиться своими полномочиями и разделять панарабскую повестку дня. Тем не менее, Семь эмиров Договорного Омана в период между 1971-1972 гг. формируют собственное федеративное государство - ОАЭ. Данный союз представлял экономические интересы местных правителей, выраженных в заинтересованности в совместном регулировании в области добычи и природных ресурсов. На сегодняшний день это единственный успешный интеграционный де-факто панарабистский проект, имеющий в своем основании, аналогичной ЛАГ, идею арабского сотрудничества. Впоследствии экономическая интеграция распространилась на все государства, имеющие выход в Персидский залив, в 1981 г. был сформирован Совет сотрудничества арабских государств Персидского залива [11].

Объединение Египта, Сирии и Ливии в ФАР по своей сути это также являлось проектом арабского сотрудничества, нежели панарабизма. Но из-за разобщенности лидеров государств, он был заранее обречен на провал. Муаммар Каддафи имел планы по созданию Арабской Исламской Республики, состоящей из Ливии и Туниса с перспективой вхождения в ее состав Алжира и дальнейшей реорганизации федерации в Соединенные Штаты Северной Африки. Но из-за разногласий в политических ориентирах руководств данных государств (Ливия - исламский социализм, Алжир - секулярный социализм, Тунис - либеральный авторитаризм), арабо-исламский североафриканский проект так и остался на бумаге [14].

В целом же ФАР не функционировала как предполагалось: не достигнув целей в новой войне с Израилем в 1973 г., окончательно объединение распалось в 1979 г., когда президент Египта Анвар Садат заключил перемирие с Израилем, в результате которого Египту был возвращен Синайский полуостров. Тем самым он поставил национальные интересы Египта выше общеарабских: страна была исключена из ЛАГ и на долгие годы была выведена из арабских интеграционных проектов [9].

Касаемо арабской интеграции в Северной Африке, идейной правопреемницей АИР в 1989 г. стал Союз Арабского Магриба (САМ), созданный в свою очередь на основе экономического союза Туниса и Марокко 1956 г. В состав САМ вошли Тунис, Алжир, Ливия, Марокко и Мавритания, являя собой пример арабского сотрудничества, однако менее продуктивного нежели ССАГПЗ [6].

Полное же сращения идей арабского национализма и арабского социализма произошла в рядах партии Баас. Ирак и Сирия имели общую баасист- 
скую идеологию. После переворотов 1963 г. и установления баасистских режимов в этих странах велись переговоры о создании единого государства.

Однако в 1966 г. партия разделилась на две ветви, праворадикальную иракскую и леворадикальную сирийскую. Тем не менее, уже после раскола руководства обеих стран предприняли новую попытку к сглаживанию внутрипартийного конфликта с дальнейшим построением объединенного союзного государства. В 1978 г. президенты Ирака и Сирии Ахмад Хасан аль-Бакр и Хафез Асад одобрили начало процесса по заключению ряда договоров касательно общего экономического и политического пространства, но вскоре после переворота Саддама Хусейна в 1979 г. переговоры зашли в тупик [3].

После баасистского переворота свое пристанище в Ираке находят изгнанные члены сирийского отделения ПАСВ, что оформило оппозиционную направленность режиму в Сирии и дало основу для развития «асадизма» и «саддамизма» в качестве векторов необааситской мысли. Так как идеология партии сочетала в себе два базиса - арабский национализм (аль-'Уруба) и социализм (аль-Иштиракийя), Хафез Асад и Саддам Хусейн переосмысливают партийные постулаты и дают им новую трактовку: для Сирии - «Социализм является основой арабского единства», а для Ирака - «Арабское единство является целью построения социалистического общества». Два этих лидера продолжали развивать панарабистскую идею, и как Насер, использовали инструмент военного конфликта. Хафез Асад призывая к исполнению общеарабского долго вмешался в гражданскую войну в Ливане, оккупировав значительную часть страны. Отметим, что дружественное Сирии центральное ливанского правительство существовало в Сирии вплоть до Революции кедров 2005 г. Саддам Хусейн использовал ту же политику во время войны с Ираном за населенный арабами Хузестан, нефтеносный остан Ирана. в последствии он оправдывал восстановлением арабского единства вторжение и оккупацию Кувейта. Данный политический ход окончательно подорвал идейную составляющую панарабизма - объявление войны братскому арабскому государству. Вторую составляющую панарабизма - социализм, уже подорванный египетской политикой Инфитаха и значительными успехами капиталистического ведения экономики в череде арабских страны. Поражение социалистического лагеря в Холодной войне и распад СССР окончательно приостановил арабскую интеграцию по панарабистской модели.

Арабский национализм был самой влиятельной политической идеологией на Ближнем Востоке на протяжении всего XX века. Достигнув некоторых из своих целей, таких как создание Лиги Арабских государств и провозглашение Объединенной Арабской Республики не смоги добиться более тесной политической интеграции, в последствии выраженной лишь региональными проектами в рамках арабского сотрудничества. Арабы упу- 
стили возможность мобилизовать массы и использовать свой панарабский энтузиазм для достижения интеграции между арабскими государствами, в результате чего главного мечта арабских националистов - создание объединенного арабского государства от Атлантического залива до Арабского залива до сих пор не осуществлена. Идеологическое противостояние увеличивало между историческими арабскими региональными сообществами. В тех странах, провозгласивших панарабизм в качестве государственной идеологии, он тесно переплетался с культом личности и служил интересам того или иного диктаторского режима.

В течение второй половины XX века панарабизм подвергся трансформации под воздействием левых идей, крушение же социалистического лагеря привело к идеологическому вакууму, заполненный исламизмом, который за последние тридцать лет укрепил свои позиции в Египте, Сирии, Ираке, Ливии, Иордании, Йемене и в значительной степени в Палестине. В ближайшем будущем панарабизм не сможет восстановить прежнюю социальную привлекательность. Некоторые типы регионального арабского национализма такие как палестинский или египетский национализм, все еще актуальны и способны мобилизовать массы, но, а в большинстве стран данные идеи продолжают терять свою популярность.

\section{БИБЛИОГРАФИЧЕСКИЙ СПИСОК:}

1. Адес Г. Египет: история страны / пер. О. Чумичевой. М.: Эксмо, 2008.

2. Добреньков В.И. Глобализация: сущность, проявления и социальные последствия. М.: Академический проект, 2018.

3. Криворучко А.П., Рощупкин В.T. Багдадский вождь: взлет и падение ... Политический портрет Саддама Хусейна на региональном и глобальном фоне. М.: Проспект, 2017.

4. Национализм в мировой истории / под ред. Тишкова В.А., Шнирельмана В.А.; Ин-т этнологии и антропологии им. Н.Н. Миклухо-Маклая РАН. М.: Наука, 2007.

5. Филиппов A.A. Концепция «Вечного Арабского послания» в идеологии М. Афляка // Минбар. Исламские исследования: Ислам на стыке времен и культур. 2010. Том III. Вып. 1 (5).

6. Фролова И.Б. Союз Арабского Магриба: Задачи, Проблемы, Перспективы // Вестник Брянского госуниверситета. 2017. Вып. 1.

7. Abu Jaber K.S. The Arab Ba'th socialist party: history, ideology and organization. Syracuse, N.Y.: Syracuse univ. press, 1966.

8. Al-'Aysami S. Unity, freedom and socialism. Transl. by Arab inst. for research and publ. Beirut: Arab inst. for research and publ., 1974.

9. Egypt: A Country Study / Ed. by Metz H.C. Washington, D.C.: U.S. Government Printing Office, 1990. 
10. Hazem Hanafi. The Limits of Integration Processes in the Arab World // The Federalist Debate. Torino: Centro Einstein di Studi Internazionali (C.E.S.I.), 2009. Vol. 1.

11. Jordan: A Country Study / Ed. by Metz H.C. Washington, D.C.: U.S. Government Printing Office, 1991.

12. Mansfield P.A. History of the Middle East. London: Penguin Books, 2003.

13. Middle East Dilemma: The Politics and Economics of Arab Integration/Ed. by Hudson M.C. Center for Contemporary Arab Studies Georgetown University: Taurius \& Co. Ltd.

14. Persian Gulf states: A Country Study / Ed. by Metz H.C. Washington, D.C.: U.S. Government Printing Office, 1994.

15. Ryzhov V.B., Shinkaretskaya G.G. World order: after the Second World War and nowadays // Международное право и международные организации. 2015. № 4.

\section{THE PROCESSES OF POLITICAL INTEGRATION IN THE COUNTRIES OF THE BIG MIDDLE EAST WITHIN THE FRAMEWORK OF THE PAN-ARABIC CONCEPT OF THE PERIOD 1945-1990}

The article discusses the need for economic, political integration processes in the Arab countries of the Greater Middle East, as well as the reasons for their failure in this region in the second half of the twentieth century.

Key words: integration, Islamism, consolidation, the Arab League, panArabism, Arab nationalism, Arab socialism, Arab cooperation. 